\title{
Orthodox Church and Science Education Policy in Modern Greece
}

\author{
Gianna Katsiampoura \\ Department of Primary Education, University of Athens, Athens, Greece \\ Email: katsiampoura@gmail.com, katsiampoura@primedu.uoa.gr
}

How to cite this paper: Katsiampoura, G. (2019). Orthodox Church and Science Education Policy in Modern Greece. Advances in Historical Studies, 8, 99-106. https://doi.org/10.4236/ahs.2019.82007

Received: January 29, 2019

Accepted: March 25, 2019

Published: March 28, 2019

Copyright $\odot 2019$ by author(s) and Scientific Research Publishing Inc. This work is licensed under the Creative Commons Attribution International License (CC BY 4.0).

http://creativecommons.org/licenses/by/4.0/

\begin{abstract}
The aim of this paper is to present the influence the Greek Orthodox Church has on matters of Education Policy in the Modern Greek state, especially on Science Education. Historically, since its foundation, the Greek state is closely linked to the Orthodox Church, which is the institution of orthodox Christianity, the official religious dogma of the Greek state as it is explicitly mentioned in the Greek Constitution. Since the foundation of the Modern Greek state, nearly two centuries ago, the Orthodox Church plays a key role in every aspect of general policy, and especially in educational policy. It is characteristic that religious affairs and education are governed by the same ministry, the Ministry of Education, Research and Religions, and orthodox priests are public employees enjoying the status of civil servants. Historically, this interlink of the Church with the State can be easily explained by the privileged relation the patriarch had with the sultan in the Ottoman empire, a status that continued to exist in a different form in the epoch of the Modern Greek state. Due to its privileged position in the state apparatus, the Orthodox Church and its multitude of official and unofficial organizations could control the educational policy and especially the national curriculum. This control is more obvious in science education. The aim of this paper is to present the influence the Greek Orthodox Church has on matters of secular education policy in the Modern Greek state, especially on the curriculum of natural sciences. Here, we don't refer to the parallel secondary education system organized by the Church, which is another point of confrontation between the Greek Orthodox Church and the Greek state in several occasions.
\end{abstract}

\section{Keywords}

Science Education, Education Policy, Contemporary Greece, Orthodoxy, Church, Evolution, Natural Sciences

\section{From the $19^{\text {th }} \mathrm{C}$. to the Interwar Period}

To examine the issue of the Greek Church's relationship with education, it is 
necessary to refer to the founding of the Greek State, because the origins of this relation are very deep. So, we will refer to some historical facts about the Greek Orthodox Church and the Greek State.

Historically, since its foundation in 1829 , the Greek state is closely linked to the Orthodox Church, which is the institution of orthodox Christianity, the official religious dogma of the Greek state as it is explicitly mentioned in the Greek Constitution. The autonomy of the Greek Church from the Ecumenical Patriarchate of Constantinople meant that the new state would be closer to the European West than the Ottoman East, i.e. a modern European state (Matalas, 2003: p. 347).

So, this autonomy was the means for building a more secular state than the Ottoman Empire, where the Patriarchate was in charge for the Christian Orthodox community-millet, playing a political role. It is worth noting here that the Patriarchate was against the Greek Revolution of 1821, as an Ottoman official institution (Kremmydas, 2016). In other words, in the first decades of the independent Greek state, the state gives an identity to the Church and not the Church to state (Kitromilides, 1989: p. 149-192).

At the second part of the $19^{\text {th }}$ century, a very turbulent period in South Eastern Europe, the Greek state used the Christian Orthodox dogma and the official Church to build Greek nationalism against the emerging nationalism of the Balkan countries, especially the Bulgarian, but also to claim territories that still belonged to the Ottoman Empire. Until then, the connection of Greek national consciousness to Orthodoxy was not self-evident. This connection is a construction of the second half of the 19th century. Historians such as Spyridon Zambelios (Zambelios, 1857) and Constantine Paparrigopoulos (Paparrigopoulos, 1860-1874) constructed a version of history that functioned as a political program of the Greek state (Anagnostopoulou, 1999).

The triptych "Fatherland, religion, family" became the official state slogan and the official state ideology and policy (Gazi, 2011). So, the Greek Orthodox Church begun to play a key role not only in the everyday life and public ideology but also at the official education policymaking of the Greek State.

A characteristic example for the increasing influence of the Church in education is the case of city of Volos' School of Girls, in the first decade of the $20^{\text {th }}$ century, a school founded by radical educators, and some of them are members of Local Trade Union Council. The local Bishop accused the directors of the school that they promoted atheism and the school closed (Charitos, 1989). Another example is the case of the Marasleion School for Primary Teachers, in the decade of 1920. In 1925, the Holy Synod of the Church accused the Director of the Marasleion School and some of the teachers for materialistic, atheistic and antipatriotic methods. As a result, the ministry of Education dismissed a number of progressive scholars, such as Alexandros Delmouzos, Dimitris Glynos, Roza Imvrioti, Michael Papamavros and the poet Kostas Varnalis (Stavridou-Patrikioy, 1999: p. 170-178).

There are also a lot of cases until the Second World War that show that the power of the church was important, regardless of the form of governance: royalty, democracy or dictatorship. 


\section{After the World War II}

The role of the Church and its direct involvement with the state became stronger after the Second World War and the Greek Civil War of 1946-1949. After winning the civil war, the Greek rightwing state took very harsh measures against the Left (imprisonment, exile, or executions were some of them). Among them, there were many teachers who were removed from public education since their role has been particularly dangerous for the transmission of communist ideas to students (Noutsos, 2003). During these years, the Church played a key role in the Civil War against the "Communists" and assisted the state to formulate a new conservative ideology based on nationalism and authoritarianism, in other words to be transformed into a modern absolutist state.

Not only the members of the Official Church but many theologians took part in the attempt to reconstruct education on the basis of Christian and anti-materialist principles. The most important Christian union was the Brotherhood "Zoe" (Life), which had been founded in 1907. According to "Zoe", education had to be based on Christian Orthodox principles, so the atheists or the teachers who had materialistic ideas had to be persecuted by the schools (Zoe, no 1633, 1948: p. 280; no 1528, 1946: p. 55). It's obvious that the Church and the religious organizations had the same attitude for the role of education and the educators. The common aim was the establishment of a Christian orthodox education for Christian orthodox people.

Especially for the sciences, from 1946, Christian Union of Scientists, the Declaration of the Christian Union of Scientists, a union closely linked to "Zoe", signifies the scientific theories which are materialistic, so the Christians have to confront them: Evolution, Relativity, quantum mechanics and psycho analysis. This Declaration, a manifesto against communism, is the basis of Christian orthodox policy for modern science and also the basis of state policy. Luckily, various scholars and scientists wrote against it (Makrides, 2004: p. 159-174).

In this political context, as mentioned before, the most important problem for the state and the Church was "Communism". For the state, the Soviet Union and the other so called Popular Republics of the Balkan Peninsula and for the Church "materialism" in science and philosophy. The Church policy against materialism meant a strong control on education. This control was exercised in all the three levels of education (primary, secondary and universities), through the official state laws for education policy, the design of the curricula, the employment of teachers etc. Due to its privileged position in the state apparatus, the Orthodox Church and its multitude of official and unofficial organizations could control educational policy and especially the national curriculum.

This control has been more obvious in science education. The main target has not been the actual content of modern scientific theories but their materialistic background and implications. So, the attitude against the teaching of natural sciences justifies the characterization of the relation model between science and religion as one of confrontation (Papandreou, 2016). 
According to the law on education of 1951 (1823/1951), at the beginning of the post-civil war era, the aim of Greek education was the development of "Hellenic Christian civilization", against communist ideology, which was the "internal enemy" for the state. A year later, in 1952, the Greek Constitution makes clearer the aim of education: "the aim of teaching is the moral and spiritual education and the development of national consciousness of young people under the ideological guidance of Hellenic-Christian civilization". ${ }^{1}$

That means that the curriculum was giving emphasis to Humanities rather than to natural sciences while the presence of apologetic religion courses was very strong, as was the existence of a lot of reviews and pamphlets by non-official Christian organizations at public schools, such as Children's Life (a publication by "Zoe") etc.

The law for education, which proposed the reformation of curriculum for secondary education, by the government of the centrist George Papandreou after the elections of 1963, met the opposition of the Church and the orthodox Christian thinkers. For them, the serious problems were the teaching of ancient Greek literature through translation in modern Greek in the first grade of secondary education, as well as the increased presence of natural sciences in the curriculum. This effort for educational reform was canceled with the fall of the George Papandreou's government, having caused many debates and hostilities among the ministry of Education, the Church and the Christian organizations (Deligiannis, 2009).

Church's privileged position in the state apparatus is clearly seen in the case of the Greek translation of the book Origins of Religions by Anatoly Lunacharsky, in 1958. The Church sued the Greek translator Vangelis Sakkatosand the book was banned. This case clearly shows the power of the Greek Orthodox Church in cultural matters (Lunacharsky, 1975).

The dictatorship in 1967 continued this educational policy, further reducing the courses of natural sciences, which accused as Marxist. A characteristic example is the theory of evolution. In 1969, the Russian biologist Theodosius Dobzhansky came to Greece, after an invitation by the Greek Anthropological Society. Greek theologians attacked him as a Darwinist, although he said that he was an orthodox Christian and he remained one until the end of his life... (Nicolaidis, 2011; Krimbas, 2017: p. 88-92).

In 1971, a textbook on biology, written by G. Oikonomides, under the title Lessons on Biology, introduces the theory of Evolution under the light of creationism. The writer presents the Evolution as a Divine will to serve the purpose of Creation. So, the God as Creator is who decides for Evolution. This textbook, which confuses Evolution with creation, culminating in unscientific conclusions, has remained for years in schools, shaping the main perception of Evolution (Oikonomides, 1971).

Even after the dictatorship of 1967-74, the Hellenic Orthodox character of education remains strong.

${ }^{1}$ Greek Constitution, 1952, § 16. 
In 1977 the textbook of Biology by K. Krimbas and I. Kalopisis, General Biol$o g y$ is introduced in the curriculum of 3rd class of Lyceum. The paragraph of the book, on page 158, which states that:

"Man and the upper primates are very close to the phylogenetic Tree and must have a common ancestor. This common ancestor would look like a Monkey, if now a mammal systemic expert lived and looked at him: This opinion was formulated by the American Simson, the most important paleontologistin our time".

Has been a cause for strong protests from the side of church groups, the clergy etc. This paragraph, from the 3rd edition of the book in 1979, is then deleted, without the author's approval (Krimbas, 2017: p. 93-94; Krimbas, 1985). ${ }^{2}$

In the decade of 1980, the government of the Greek Socialist Movement (PASOK) made same changes in the curricula, but when it tried to introduce the theory of Evolution, the church reacted with anger and these changes were removed... The textbook History of the Humankind has been authored by Dr. Lefteris Stavrianos (1913-2004), a famous leftist historian, professor of history at University of California, San Diego, until 1992. The textbook published under the auspices of the National Hellenic Organization of School Textbooks (OEDB), the official organization of Ministry of Education and Religion. ${ }^{3}$

The chapter of Stavrianos' textbook described the history of humankind not only under the Darwinian view of Evolution but also tried to introduce the concept, according to the Dialectics of Nature by F. Engels, that man constructs the human culture through his work, because the human is the only kind who can work rationally.

This materialistic and dialectical view of human creation, which Stavrianos had always present in his book Man the toolmaker (Stavrianos, 1973), provoked a reaction by the Greek conservatize political party and the Church. The debate between the church, theologians, scholars and journalists, on one hand, and the supporters of the book, on the other, was intense. ${ }^{4}$ Finally, at the end of 80 s, the

\footnotetext{
${ }^{2}$ As refers the author C. Krimbas, in his letter to newspaper Vima, 20.01.1985.

${ }^{3}$ It has to be noted that OEDB produces each year the school textbooks for primary and secondary education and distributes them freely to the student population.

${ }^{4}$ There are a lot of written sources about this debate. Among others, the question to parliament from 29.11.84 by members of Greek Parliament and also of New Democracy political party (I. Varvitsiotis, K. Paparigopoulos, K. Simeoforidis, Th. Choutas) where they accused the textbook that it aims at spiritual malnutrition of students, erosion of tissue consistency with national all in their alienation from the religious community, and the memorandum by Holy Synod of Greek Church to Ministry of Education and Religion against the book (from 8.2.1985). Also, the encyclical 403/13.3.1985 by Augustine Kantiotis, Bishop of Florina. Part of the same category of sources are the articles on newspapers and journals, against the book (K. Georgousopoulos, Nea, 17.9.1984 and 19.1.1985, Bradyni 20.11.1984, Christianiki 12.1.1985, Kathimerini 14.2.1985, 24 and 25.2.1985 by theologist St. Ramfos). As well as, a pamplet of metropolitan of Peiraias, Kallinikos, under the title Man from monkey? Reply to the materialist thesis (1987). On the other hand, articles by the defenders of textbook, specially by academics (Dimosthenis Kourtovic, Scholiastis v. 24, D. Kyrtatas and George Margaritis, Politis Dekapenthimeros 24.2.1985), as well as an interview by the writer Lefteris Stavrianos (Scholiastis, v. 27, 1985). Also, books and articles which describe this conflict. As example, the book of Athanasios Nikas, Church and Education (Athens 1991), article in Eleftherotypia from 30.7.2000, etc.
} 
Ministry of Education was forced to withdraw the book. It is worth noting here, that until now the theory of evolution it is taught in the classrooms only for 5 hours in the $3^{\text {rd }}$ class of Gymnasium and it not exists in the curriculum of the Lyceum...

\section{The Situation after 1989}

It's clear that the traditional interdependence of the church and the state is a very strong heritage for Greek national policy. Moreover after 1989, when the state relied on church and orthodoxy for foreign policy in the Balkans. Even today, as we can see in the Greek Constitution, the close relation between the state and Orthodox religion is very strong.

The Greek Constitution, even after the revision in 2008, in the "Preamble" states: "In the name of the Holy and Consubstantial and Undivided Trinity". Although in Second Part, article 13, paragraph 1, the Constitution states that the freedom of religious conscience is Inviolable, in the First Part, under the title "Relation between the Church and the State", the orthodox Christian character of the state is reassured: "Prevailing religion in Greece is the Orthodox Christian religion". In article 16, paragraph 2, this privilege is defined clearly: "Education constitutes a basic mission of the state and its aim is the moral, intellectual, professional and physical education of Greeks, the development of national and religious consciousness". ${ }^{5}$ All the laws for education, by the ministry of Education, Research and Religious Affairs, are based on the last sentence, under the view of the prevailing orthodox Christian religion. It is interesting to note here the title of the relevant ministry itself: ministry of Education, Research and Religious Affairs, which means that education is closely related with religion. The modern principles of secularism and rationality coexist with the traditional values of religious proselytism. In the European Union, only in Greece and Ireland the Public education has a character of proselytism with extreme characteristics (Zampeta, 2003).

It's obvious that the crucial issue for Greek education is the teaching of natural sciences, especially of biology or biosciences.

The controversy about the curriculum continues to focus on Evolution. Although, recently, the reactions of the Greek Christian Orthodox side vary. The official Church, through the Holy Synod, hasn't issued any statement on this subject, but some bishops systematically write and publish against Evolution. For example, Seraphim, bishop of Piraeus, in 2012, in his book Universe

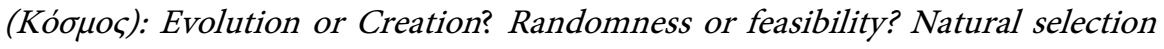
or Divine providence? Argues against Evolution, supporting a kind of theory of creation (Serapheim, 2012).

On the other hand, another category of Orthodox thinkers, through the review Aktines, edited by Society of Christian Scientists, which is related with Zoe Brotherhood, as mentioned before, centered to relation between Darwin himself ${ }^{5}$ http://www.hellenicparliament.gr/UserFiles/8c3e9046-78fb-48f4-bd82-bbba28ca1ef5/SYNTAGMA1 $=1 . \mathrm{pdf}$. 
and Christianity. Their effort to promote this relation focuses to the proof that Evolution can coexist with Christianity, since Darwin was a Christian, not an atheist or an agnostic (Gamvrias, 2010; Ketseas, 2009).

In the last years, the attitude of the Church towards natural sciences, according to the official announcements by the Holly Synod, follows the view of Basil of Caesarea in Address To Young Men On How They Might Derive Benefit From Greek Literature. So, the official statements about education focus on humanities and apologetic religion courses, because, according to the Church's position, these are more useful for young people than natural sciences. For the Church, the aim is a moral-Christian education, which is identified with the Greek tradition. According to official statements, natural sciences are useful for everyday life but sometimes dangerous for faith, because without knowledge of the Greek orthodox tradition they could relate favourably with atheism or agnosticism. There are a lot of publications that present this attitude, from clerics, theologians or other scholars (Marnellos, 1991; Kallinikos, 2011). ${ }^{6}$

\section{Summarizing}

Today, the attitude of the church towards secular education is to promote classical Greek education, which is considered to constitute the Greek-Christian culture, and in terms of science, control over their content. Thus, the Church is still seeking to control the content influencing the design of education curricula in order to conform to religious standards related favourably to religious value. The state, on the other hand, although has the official control of education, hasn't promoted the principles of secular education. This is an ambiguous situation, which still influences the content of the curriculum in Greek primary and secondary schools.

\section{Supported}

This publication has been implemented within the framework of the project "Science \& Orthodoxy around the World" of the Institute of Historical Research of the National Hellenic Research Foundation, which was made possible through the support of a grant from the Templeton World Charity Foundation, Inc. The opinions expressed in this publication are those of the authors and do not necessarily reflect the views of the Project and the Templeton World Charity Foundation, Inc.

\section{Conflicts of Interest}

The author declares no conflicts of interest regarding the publication of this paper.

\section{References}

Anagnostopoulou, S. (1999). The Historicity of the "National Role" of the Church of

${ }^{6}$ As example, among others, Ecclesia, January 2008, 2014, 2015, 2016, 2017. 
Greece: Greek Nation or Greek-Orthodox Nation. Structures and Power Relations in Contemporary Greece. Athens: Panteion University of Social and Political Sciences.

Charitos, Ch. (1989). Volos' School of Girls. Athens: Historical Archive of Greek Youth.

Christian Union of Scientists (1946). Declaration of the Christian Union of Scientists. Athens.

Deligiannis, D. (2009). The Review "Greek-Christian Education" and the Educational Reform of 1964. MA Thesis, Ioannina: University of Ioannina.

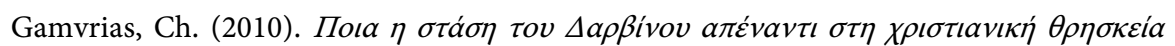
(Vol. 708). Aktines.

Gazi, E. (2011). Country, Religion, Family. The History of a Slogan (1880-1930). Athens: Polis.

Kallinikos, Bishop of Paronaxia (2011). Education According the Jesus Christ. Ecclesia.

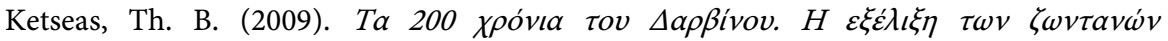

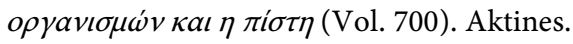

Kitromilides, P. (1989). "Imagined Communities" and the National Question in the Balkans. European History Quarterly, 19, 149-192. https://doi.org/10.1177/026569148901900203

Kremmydas, V. (2016). The Greek Revolution of 1821. Athens: Gutenberg.

Krimbas, C. V. (1985). Letter. Newspaper Vima, 20.01.1985.

Krimbas, C. V. (2017). Darwinism in Greece. Athens: National Hellenic Research Foundation.

Lunacharsky, A. (1975). Introduction to the History of Religions. Athens: Alfeios.

Makrides, V. N. (2004). Orthodoxy in the Service of Anticommunism: The Religious Organization Zoe during the Greek Civil War. In P. Carabott, \& T. D. Sfikas (Eds.), The Greek Civil War: Essays on a Conflict of Exceptionalism and Silences (Vol. 6). Publications for the Centre for Hellenic Studies, King's College London, Aldershot: Ashgate.

Marnellos, G. (1991). The New Man in "Secular" Education and the Duty of the Church. Chania.

Matalas, P. (2003). Nation and Orthodoxy. The Adventures of this Relationship. Herakleion: Crete University Press.

Nicolaidis, E. (2011). Science and Eastern Orthodoxy: From the Greek Fathers to the Age of Globalization. Chicago: The John Hopkins University Press.

Noutsos, Ch. (2003). Education Policy in Greece 1944-1846. Athens: Bibliorama.

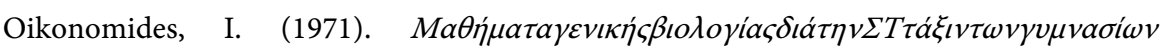
(General Biology). Athens: National Hellenic Organization of School Textbooks.

Papandreou, A. (2016). Dialogue between Science and Religion in Greece at the End of the 20th Century: The Impact on Education and Teaching of Natural Sciences. MA Thesis, Patra: Hellenic Open University.

Paparrigopoulos, C. (1860-1874). History of the Greek Nation. Athens.

Serapheim, Metropolitan of Piraeus (2012). Universe: Evolution or Creation. Piraeus.

Stavrianos, L. (1973). Man the Toolmaker. Chicago: Follet Publishing and Co.

Stavridou-Patrikiou, R. (1999). Language, Education and Politics. Athens: Olkos.

Zambelios, S. (1857). Byzantine Studies: On the Sources of Modern Greek Ethnicity. Athens.

Zampeta, E. (2003). School and Religion. Athens: Themelio. 